\title{
Editorial
}

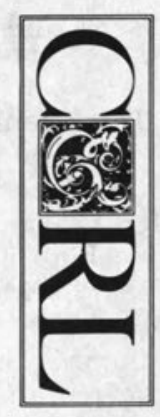

\section{Elysian Thoughts on Librarians as Faculty}

Preceding the American Library Association Midwinter Conference in January 1992, the Association of College and Research Libraries (ACRL) Committee on Academic Status invited twelve academic librarians to participate in a Think Tank on Faculty Status. The participants were Mignon Adams, Joan Giesecke, Kathy Jackson, Beverly Lynch, Olivia Madison, Bede Mitchell, Barbara Moran, Jim Murphy, Lester Pourciau, Gloriana St. Clair, Janet Steins, and Rebecca Watson-Boone. Think Tank Task Force Sub-Committee members were Irene Hoadley, Larry Oberg, Gemma DeVinney, Tom Patterson, and Mary Reichel. They assembled the Think Tank to identify strategic directions for the Committee on Academic Status. Irene Hoadley and I made a few remarks to summon the sibyl. Maureen Sullivan, from the Association of Research Libraries (ARL), facilitated to keep the group on its Herculean task. This editorial reports the substance of the work: relationships with administrators and teaching faculty, tenure and its ramifications, and the roles of ACRL.

One key relationship discussed was that between campus administrators and the libraries. Being seen as working in cooperation with the administration is a political priority for every college and university library director. On many campuses, serials price increases in the past decade have complicated this task even for the most accomplished library director. College and university administrators continue to face the prospect of either supplying scarce additional financial resources to libraries to cover serials cost increases or listening to faculty complain about a lack of support for essen- tial academic programs when serials cuts are instituted because of declining buying power. Like Cassandra, the library director must again and again prophesy doom, only to see the prophecies ignored, then watch the anguish of a serials cancellation project with campus reverberations.

The causes of this Sisyphean endeavor are better understood by communication with on-campus academic administrators. Library directors who are faculty do this by working as peers with other administrators. Nonfaculty library directors at some institutions do this by meeting regularly with a council of deans. The Think Tank's consensus was that being part of a legitimate, regular deans' meeting facilitates communication with other campus academic administrators.

Think Tank participants also valued relationships with teaching faculty. Faculty librarians serve as full voting members of the faculty senate and its committees. On some campuses, librarians who are not faculty may have this same opportunity to participate in campus governance, but research has shown that that is frequently not the case. The forum of the faculty senate allows librarians to share the library's story through words and actions. Doing so earns them, and the profession they represent, respect.

Because tenure is no longer being granted to academics in higher education in Great Britain, discussion about not continuing that system has once again surfaced in the United States. The discussion is particularly relevant now because, with the country in a recession, job security has become a strong concern for librarians and teaching faculty. Yet 
Think Tank participants believed that if tenure no longer exists for teaching faculty, then librarians must share that increased anxiety about job security.

Think Tank members also believed that librarians should maintain control over the process of judging merit in librarianship, professional activities, research, and service. The process calls for a faculty peer review committee to give an initial recommendation on whether a faculty member should continue in an appointment. Non-faculty librarians frequently use the same process. Difficulties arise when teaching faculty are judged by a publish or perish standard with little credit for excellence in teaching. However, Think Tank members agreed that both teaching and librarianship are hard to judge by anything more challenging than numbers of assignments, impressions of colleagues, and subjective analysis of students. Assessment of quality performance needs more thought and research for both teachers and librarians.

Librarians as professionals must educate academic administrators and faculty colleagues about the value and contribution of librarianship to the entire education process. Several recent ACRL presidents have identified dialogue with campus constituents as a high priority. And the ARL has worked to increase the visibility of librarians in the education press. The Think Tank members reiterated the necessity of communicating the message of libraries and librarianship beyond the profession.

The Think Tank ascribed to the conviction that ACRL played several key roles in furthering a goal of faculty status for librarians. These roles are publication, continuing education, and defense of those with threatened faculty status.

\section{PUBLICATION}

Professional organizations foster change, establish professional mores, and direct the growth of the discipline through the publication of a professional literature. Through the process of selecting an editor, editorial board members, and referees, association officers imprint their vision of the future on the permanent literature in their field. CERL plays out a role apropos of librarians as faculty by providing a top-ranked journal to legitimize and disseminate research done by librarians.

\section{CONTINUING EDUCATION}

ACRL does not depend on publication alone to keep member competencies current. The association also sponsors a large number of programs on local, regional, and national levels. In these forums, members have an opportunity to discuss their research, to share strategies on common problems, and to cooperate to improve library services. The Committee on Academic Status may increase its offerings to members by focusing in future programs on how to do research, how to prepare understandable librarian dossiers, and how to validate librarianship as a substitute for teaching in promotion and tenure evaluations.

\section{DEFENSES}

In the open forum of the Think Tank, representatives from two campuses reported on attempts by new provosts to change librarians' status from faculty to staff. The Academic Status Committee typically provides guidance for librarians in such situations. Proven defense strategies are suggested and attempts are made to discover the cause of the threat. ACRL may send letters outlining the Association's position and reminding administrators of the consequences of their actions. Think Tank members believed that more activities such as these should be developed to educate provosts about the benefits of having librarians who are faculty.

Recently, ARL published Spec. Kit 182, titled Academic Status for Librarians in $A R L$ Libraries. ${ }^{1}$ In the flyer, editor Jack Siggins reports that sixty-six out of ninety-nine responding ARL libraries have faculty or academic status for librarians who are, thus, eligible for tenure or continuing appointment. The extent to which these numbers reflect the circumstances of college and other university librarians is not known. With ACRL's stated goal in mind that all aca- 
demic librarians should be faculty, the Think Tank members concluded the day by working on a vision statement. That vision is to achieve parity with teaching faculty at all academic institutions. For the Think Tank, parity included protection through the due process of tenure, equitable compensation, a faculty established process for promotion, and participation in campus governance. The preferred method for achieving parity is by becoming faculty.

Think Tank members agreed without discussion that being faculty was the most valuable mode of participation in campus life. I value my faculty appointment because I believe that research is necessary to the provision of excellent li- brary service and because I can interact more effectively for the library with campus colleagues. Campus society is not egalitarian; scientists look down on engineers and social scientists, who look down on liberal and fine arts faculty. All look down on librarians. However, I would rather serve at the bottom of the faculty hierarchy than in some "other" status.

For me, being faculty is the Olympian solution to where librarians fit in the university. From that peak, librarians have the best view of the evolving campus contours. The climb is difficult, the atmosphere is thin, and the opportunities to fall off are numerous, but the perspective makes it all worthwhile.

GLORIANA ST. CLAIR

\section{REFERENCE}

1. Jack Siggins, ed., Academic Status for Librarians (Washington, D. C.: Assn. of Research Libraries, Office of Management Services, 1992), [flyer].

\section{IN FORTHCOMING ISSUES OF COLLEGE \& RESEARCH LIBRARIES}

Surveying the Damage: Academic Library Serial Cancellations from 1987-88 to 1989-90

Tina E. Chrzastowski and Karen A. Schmidt

A Current Awareness Service Using Microcomputer Databases and Electronic Mail John T. Butler

Collective Bargaining and Faculty Status: A Twenty-Year Case Study of Wayne State University Librarians

Lothar Spang

Recognizing Multiple Decision-Making Models: A Guide for Managers Joan Giesecke

Indexing Adequacy and Interdisciplinary Journals: The Case of Women's Studies Kristin H. Gerhard, Trudi E. Jacobson, and Susan G. Williamson

Instruction Librarians: Acquiring the Proficiencies Critical to Their Work Diana Shonrock and Craig Mulder 


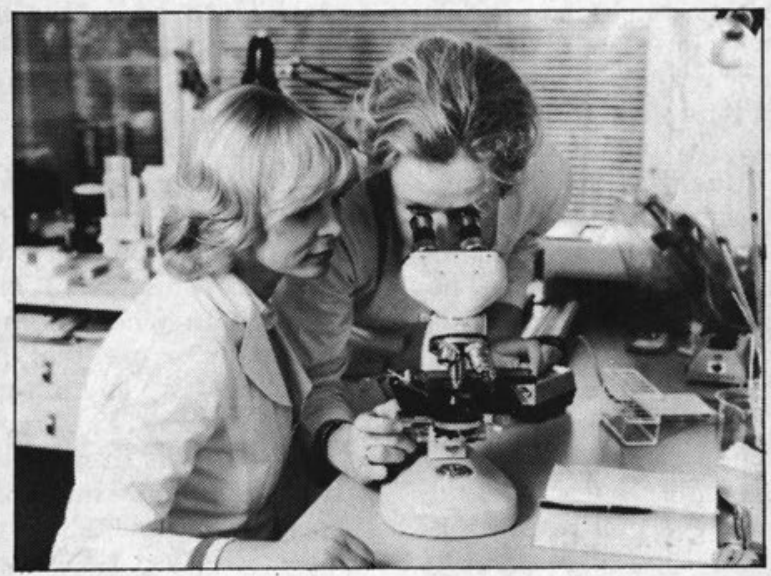

\section{World-Class Discoveries}

....begin with world-class information. It's the kind of information you'll find in Biological Abstracts ${ }^{\circ}(B A)$ and Biological Abstracts/RRM ${ }^{\circ}$ (Reports, Reviews, Meetings) (BARRM).

\section{Comprehensive Coverage...}

...sets $B A$ and $B A V R R M$ apart from other reference materials. $B A$ contains full bibliographic information and abstracts from the latest biological and biomedical literature, carefully selected from nearly 7,000 journals worldwide. BARRM supplies exhaustive coverage of papers from international meetings and symposia, as well as books, reviews and other items not found in most life science reference tools.

\section{A Solid Information Foundation...}

...for life science research is yours with $B A$, $B A R R M$ and their Cumulative Indexes. Together, this powerful information package provides thorough, accurate coverage of the research that can lead to world-class discoveries!

Call today for your free copy of How to Use Biological Abstracts and Biological Abstracts/RRM! 1-800-523-4806 (USA except PA); (215) 587-4800 (worldwide); Internet: BIOSIS@A1.RELAY.UPENN.EDU. Or, simply return the coupon.

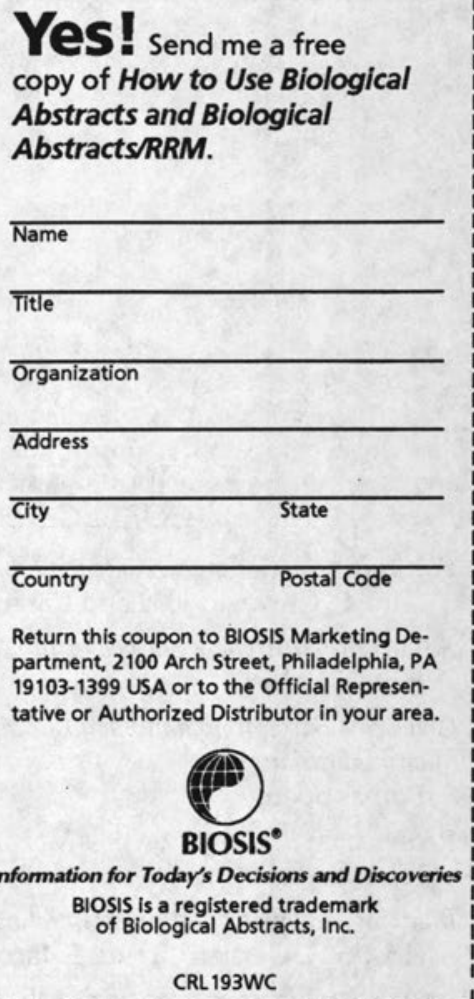

